Aldona Zakrzewska*

Olsztyn

\title{
Wielorakość kulturowo-religijna a wychowanie obywatelskie w szkole katolickiej
}

Wychowanie obejmuje szerokie spektrum działań odnoszących się do wielu płaszczyzn życia człowieka: biologicznej, społecznej, psychicznej, duchowej, kulturowej. Każdy człowiek osadzony jest zatem także w danej kulturze. Z jednej strony ta kultura go kształtuje i warunkuje jego tożsamość. $\mathrm{Z}$ drugiej jednak, coraz bardziej obecny proces globalizacji świata sprawia, że niejednolite kultury stykają się ze sobą, a nawet wręcz przenikają. To współżycie różnych kultur w granicach danego regionu, państwa czy kontynentu uwarunkowane jest również światopoglądowo, stąd też w podjętych rozważaniach odnoszę się do różnorodności kulturowo-religijnej.

Z uwagi na to, że - jak zaznaczyłam na wstępie - wszystkie płaszczyzny życia człowieka, w tym sfera kulturowo-religijna, odnoszą się do edukacji, dlatego też w pierwszej kolejności poruszam kwestie wzajemnych relacji zachodzących między wielorakością kulturowo-religijną a procesem dydaktyczno-wychowawczym obecnym w szkołach. Następnie swoje zainteresowanie ograniczam do polskiej szkoły katolickiej - jako przykładu placówki, przenikniętej w stosowanej edukacji określonym światopoglądem. Na za-

* Dr Aldona Zakrzewska jest adiunktem w Wydziale Nauk Społecznych Uniwersytetu Warmińsko-Mazurskiego w Olsztynie, w Katedrze Dydaktyki i Historii Wychowania. Adres: Wydział Nauk Społecznych Uniwersytetu Warmińsko-Mazurskiego w Olsztynie, ul. Romana Prawocheńskiego 13, 10-720 Olsztyn; e-mail: aldona61@wp.pl. 
kończenie zaś poddaję analizie wychowanie obywatelskie szkół katolickich $\mathrm{w}$ odniesieniu do jego roli w sferze kształtowania w dzieciach i młodzieży świadomości międzykulturowej, otwartości na wszechogarniające świat społeczeństwo wielokulturowe.

\section{Edukacja w różnorodności kulturowo-religijnej}

Wielokulturowość jest faktem i ona dotyka także polskie społeczeństwo, a Polacy stykają się z ludźmi o różnych kulturach i religiach nie tylko w kraju, ale coraz częściej także poza jego granicami. Taki stan rzeczy spowodowany został przez wielowarstwowe i długofalowe procesy. Marian Golka zauważa, iż

najpierw procesy migracyjne oraz wszelkie ruchy ludności spowodowane działaniami cywilizacyjnymi, militarnymi czy gospodarczymi, a dzisiaj procesy globalizacyjne przyczyniły się i przyczyniają do przemiany różnokulturowości ludzkiego świata w jego wielokulturowość (czy raczej w szczególną jej postać - transkulturowość), dodając do dotychczasowych przejawów wielokulturowości miast, regionów i państw, wielokulturowość z jednej strony wewnątrzosobową, a z drugiej - globalną ${ }^{1}$.

Wielokulturowość jest pojęciem, którego etymologia odnosi się do angielskiego terminu multiculturalism. Jest ono wieloznaczne. Encyklopedia $P W N$ przywołuje trzy jego znaczenia. Pierwsze odnosi się do płaszczyzny opisowej i oznacza obiektywne istnienie wielości kultur - „fakt istnienia na świecie odmiennych kultur etnicznych, grup religijnych, subkultur itp.”. Drugie z kolei dotyczy polityki państwowej prowadzonej w celu zniwelowania napięć społecznych wynikających $\mathrm{z}$ faktu funkcjonowania $\mathrm{w}$ danej populacji grup zróżnicowanych kulturowo. Natomiast trzecie znaczenie charakteryzuje działania określonych ,środowisk mniejszościowych skierowanych na emancypację i pełniejszy udział różnych środowisk w życiu społecznym, politycznym i kulturowym kraju"2.

${ }^{1}$ Marian Golka, Imiona wielokulturowości (Warszawa: Warszawskie Wydawnictwo Literackie MUZA SA, 2010), 7.

2 „Wielokulturowość”, w: Encyklopedia PWN, https://encyklopedia.pwn.pl/haslo/wielokulturowosc;3995791.html (dostęp: 10.10.2017). 
Marian Golka wyjaśnia, że:

wielokulturowość to uświadomione współwystępowanie na tej samej przestrzeni dwóch lub więcej grup społecznych o odmiennych cechach kulturowych, takich jak wygląd zewnętrzny, język, wyznanie religijne, układ wartości itd. Przyczynia się ona do wzajemnego postrzegania odmienności z różnymi tego skutkami - od antagonizmu i konfliktu do pełnej akceptacji i współdziałania ${ }^{3}$.

Natomiast samo pojęcie ,wielokulturowości służy do opisu rzeczywistych przejawów współwystępowania różnych grup i ich kultur"4.

Postępujące procesy społeczne, a w konsekwencji wzrastająca i zmieniająca się wielokulturowość świata, zmuszają wręcz decydentów poszczególnych państw do podjęcia na płaszczyźnie instytucjonalnej wychowania ukierunkowanego na kształtowanie w młodych pokoleniach postaw akceptacji i harmonijnego funkcjonowania wielorakości kulturowo-religijnej w jej różnych przejawach terytorialnych: regionalnych, państwowych, globalnych - czyli do pełnego wykorzystania edukacji międzykulturowej. Podkreśla się wręcz, że jest to niezwykle istotne, ponieważ edukacja stanowi jedną z ważnych dróg wejścia w świat wielu kultur.

Tak traktowana edukacja kształtuje w człowieku pewnego rodzaju nawyk poznawania świata nie tylko w jego płaszczyznach dziejowych, ale także kategoriach inności kulturowej czy wyznaniowej. Daje również szansę na to, iż człowiek będzie odnosił się do innej kultury czy religii nie jako do zagrożenia, tylko jako do okazji na pozyskanie doświadczeń, wzbogacenie możliwości postrzegania świata. Istotne $\mathrm{w}$ działaniach edukacyjnych jest to, aby nie przebiegały one tylko etnocentrycznie, ale aby przybrały formę procesu kształtowania w dzieciach i młodzieży postaw rozwijających otwarte i pokojowe interakcje w społeczeństwie zróżnicowanym kulturowo. Ten wymiar edukacji określany jest w pedagogice mianem edukacji dla wielokulturowości, a czasami zamiennie także edukacji wielokulturowej, międzykulturowej czy etnicznej ${ }^{5}$.

3 Golka, Imiona, 7-8.

4 Tamże, 9.

5 Tamże, 292-297. 
Polscy naukowcy zajmujący się edukacją dla wielokulturowości (m.in. Jerzy Nikitorowicz ${ }^{6}$, Marian Golka ${ }^{7}$, Alicja Szerląg ${ }^{8}$ ) wyróżniają kilkanaście elementów, które determinują jej powodzenie. Na plan pierwszy wysuwa się tu kształtowanie nieustannej ciekawości świata w jego różnorodności wraz ze zdolnością jego rozumienia w sferze życia społecznego. Podkreśla się także rozpowszechnianie idei polifonicznego postrzegania świata wraz z uznawaniem każdej kultury za równowartościową oraz godną zainteresowania, a nawet konstruktywnego wykorzystania pewnych jej elementów. Istotne jest również ukazanie, iż widzenie świata ukształtowane w jednostce osadzonej w danej kulturze nie musi być uniwersalne, a „niezrozumiałe” zachowania przedstawicieli innych kultur mogą wynikać z kontekstów historycznych, wyznaniowych czy społecznych i nie muszą prowadzić do destrukcyjnych polemik.

Dodatkowo, w edukacji dla wielokulturowości duży nacisk kładzie się na właściwe gospodarowanie zasobami indywidualnych emocji, ich stosowne ukierunkowanie wobec jednostek i społeczeństw reprezentujących odmienne style życia, z jednoczesnym propagowaniem krytycznej refleksji na temat swojej kultury oraz ufności w relacjach interpersonalnych, dalekich od utartych stereotypów, ksenofobii i megalomanii. W zakresie tak pojmowanej edukacji odnajdujemy powszechny element wychowania obywatelskiego, które opiera się na odpowiedzialnym działaniu na rzecz dobra wspólnego wszystkich jednostek danego regionu czy państwa - stąd też jej nieodzowną cechą jest szerzenie „ducha” opieki nad grupami mniejszościowymi w zakresie ich rozwoju społecznego, stworzenia dla nich równych szans, pomocy w odnalezieniu swego miejsca w grupie o dominującej kulturze.

6 Jerzy Nikitorowicz, Edukacja regionalna i międzykulturowa (Warszawa: Wydawnictwa Akademickie i Profesjonalne, 2009); Jerzy Nikitorowicz, „Ku jakim strategiom w edukacji międzykulturowej w kontekście współczesnych problemów wielokulturowości?", Pogranicze 25 (2015): 25-40; Jerzy Nikitorowicz, „Edukacja międzykulturowa w procesie przeciwstawiania się dehumanizacji i infrahumanizacji”, Edukacja Międzykulturowa 1 (2017): 19-35.

${ }^{7}$ Marian Golka, „Zadania i nadzieje edukacji dla wielokulturowości”, Europa Wschodu i Zachodu 4 (2000): 12-16; Marian Golka, „Kształty wielokulturowości”, Pampaedia 6/7 (2009/2010): 7-21; Marian Golka, „Doświadczanie tożsamości w warunkach wielokulturowości”, Przeglad Zachodni 1 (2012): 3-16.

${ }^{8}$ Alicja Szerląg, Ku wielokulturowości: aksjologiczny sens wychowania w rodzinie na litewskim pograniczu kulturowym (Kraków: Oficyna Wydawnicza Impuls, 2001); Edukacja obywatelska w społeczeństwach wielokulturowych, red. Alicja Szerląg (Kraków: Oficyna Wydawnicza „Impuls”, 2007). 
Obcojęzyczni autorzy, zgłębiający problematykę edukacji dla wielokulturowości (m.in. George A. Borden ${ }^{9}$, Michael J. Collier ${ }^{10}$, Brunon Bartz ${ }^{11}$ ), zaznaczają też, że kluczową sferą w edukacji instytucjonalnej jest praca nad mechanizmami i środkami kompetencji komunikacyjnych człowieka żyjącego w świecie różnorodnym kulturowo. Wynika to z faktu, iż w styczności z innością może dochodzić do napięć, stąd też współczesny człowiek powinien zostać „wyposażony” w umiejętności porozumiewania się, negocjacji i konstruktywnego rozwiązywania konfliktów. Szczególnie to jest istotne, ponieważ stanowi wstęp do kształtowania w młodym pokoleniu tzw. wielokulturowej kompetencji działania, a więc wszelkich umiejętności nieodzownych dla właściwego funkcjonowania każdej jednostki z osobna w społeczeństwie wielokulturowym. Związane jest to zwłaszcza z coraz bardziej globalną gospodarką, co pociąga za sobą konieczność nabycia nowych kompetencji, dotyczących między innymi zjawiska konkurencji o miejsca pracy, radzenia sobie $\mathrm{w}$ mediacjach i negocjacjach między ponadnarodowymi partnerami.

Klamrą spinającą cechy konieczne dla właściwie pojętej edukacji dla wielokulturowości wydaje się jednak to, co stanowi istotę każdego procesu edukacyjnego, a mianowicie ukształtowanie szacunku wobec każdego człowieka pojmowanego w kategorii niezbywalnej wartości, niezależnie od jego koloru skóry, języka, jakim się posługuje, narodu, z jakiego się wywodzi, państwa, jakie zamieszkuje, kultury, która go ukształtowała, czy też religii, jaką wyznaje, i wartości, którymi kieruje się w życiu ${ }^{12}$.

Tak pojmowana edukacja dla wielokulturowości ma prowadzić do humanizacji stosunków międzyludzkich, do braterstwa pozbawionego rasizmu, etnocentryzmu i wrogości. Musi ona jednak uwzględniać nie tylko „kulturowy pluralizm”, ale także „strukturalny pluralizm”. Tak więc z jednej strony ma kształtować akceptację różnorodności, heterogeniczności kulturowej,

${ }^{9}$ George A. Borden, „Orientacja kulturowa. Teoria służąca rozumieniu i badaniom komunikacji międzykulturowej”, w: Komunikacja międzykulturowa: zderzenia i spotkania, red. Alina Kapciak, Leszek Korporowicz, Andrzej Tyszka (Warszawa: Instytut Kultury Uniwersytetu Warszawskiego, 1996), 57-76.

${ }^{10}$ Michael J. Collier, „Rozmowy między rodzimymi grupami kulturowymi: różnice kompetencji międzykulturowych”, tłum. I. Parowska, w: Komunikacja międzykulturowa: zderzenia i spotkania, red. Alina Kapciak, Leszek Korporowicz, Andrzej Tyszka (Warszawa: Instytut Kultury Uniwersytetu Warszawskiego, 1996), 323-337.

${ }^{11}$ Brunon Bartz, Idea wielokulturowego wychowania w nowoczesnych spoleczeństwach (Radom: Instytut Technologii Eksploatacji, 1997).

12 Golka, Imiona, 298-303. 
z drugiej zaś modelować respektowanie pewnych całości społecznych - czyli formować pluralizm przejawiający się w odrębności, niezależności, połączony z uznaniem pewnych społecznych powiązań i współzależności ${ }^{13}$. Mówiąc za Hansem Georgiem Gadamerem - wyrabiać w młodych ,rozpoznawanie w innym i jego odmienności, i tego, co wspólne"14 lub - przywołując słowa Alaina Finkielkrauta - kształtować „zdolność rozpoznawania człowieka przez człowieka" 15 , co jego zdaniem możliwe jest dzięki poznaniu i uznaniu obopólnego cierpienia.

Działania podejmowane na płaszczyźnie edukacji dla wielokulturowości mogą przybierać różnorakie formy. Jolanta Miluska proponuje cztery strategie, które stosowane razem mogą prowadzić do humanizacji społeczeństw różnorodnych kulturowo-religijnie. Są to: droga transmisji kulturowej (przekazywanie wiedzy o innych kulturach, co ma prowadzić do ich poznania i przekonania o ich wartości i równoprawności); taktyka kontaktu (aranżowanie pozytywnych kontaktów pośrednich i bezpośrednich z ludźmi reprezentującymi inne kultury w celu przełamania lęku wobec inności kulturowo-wyznaniowej); procedura autopoznania (zachęcanie do poznania siebie, wraz ze swymi uprzedzeniami i niechęciami wobec innych); strategia kompetencji (praca nad sobą w celu pozyskania nowych kompetencji w zakresie komunikacji interpersonalnej w relacji z ludźmi o innych poglądach, wartościach, wyznaniu) ${ }^{16}$.

\section{Szkoła katolicka w tyglu edukacji międzykulturowej}

Podkreśla się, że szkoła powinna wspierać edukację międzykulturową ${ }^{17}$. Jak realizują to szkoły katolickie? Czym różnią się w tej płaszczyźnie działalności od innych placówek edukacyjnych?

Warto na początku uzmysłowić sobie, czym różni się szkoła katolicka od szkoły państwowej. Jej tożsamość determinują głównie następujące ce-

13 Tamże, 303-304.

14 Cyt. za: tamże, 304.

15 Tamże.

16 Jolanta Miluska, „Ku tolerancji: program wspomagania rozwoju tożsamości kulturowej”, w: Edukacja międzykulturowa. W kręgu potrzeb, oczekiwań i stereotypów, red. Jerzy Nikitorowicz (Białystok: Trans Humana, 1995), 309.

17 Beata A. Orłowska, „Edukacja religijna jako podstawa dialogu między kulturami”, Perspectiva. Legnickie Studia Teologiczno-Historyczne 2 (2012): 135. 
chy: chrystocentryzm, wymiar ewangelizacyjny placówki, odwołanie się do czynników nadprzyrodzonych i uniwersalizm. Pokrótce je scharakteryzuję.

Specyfiką szkoły katolickiej jest w pierwszym rzędzie chrystocentryzm, czyli przyjęcie i włączenie w konkretne życie wspólnoty szkolnej transcendentnej pedagogii Chrystusa - Nauczyciela ${ }^{18}$. Każdy przejaw życia placówki katolickiej odnosi się do Jego osoby i nauki ${ }^{19}$. Cecha ta stanowi podstawę jej funkcjonowania, co wyraża się we wszelkich dokumentach placówki, głównie w programie profilaktyczno-wychowawczym i dydaktycznym, ponieważ „sercem [jej - A. Z.] działalności wychowawczej (...) jest Chrystus, stanowiący wzór, według którego chrześcijanin powinien kształtować swe życie"20.

Wśród specyficznych cech szkoły katolickiej wymienia się także jej rolę ewangelizacyjną. Zgodnie z nauczycielską misją Kościoła - ma ona głosić w swych działaniach Chrystusa i przygotowywać młodych do bycia Jego świadkiem w każdej płaszczyźnie swego życia ${ }^{21}$. Jej rola ewangelizacyjna zespolona jest ze wspieraniem rozwoju osobowego uczniów ku ich dojrzałości ludzkiej i chrześcijańskiej. Realizację tego modelu umożliwia wypracowana pedagogia szkoły katolickiej, której podstawy teoretyczne stanowią: pedagogika personalistyczna ${ }^{22} \mathrm{z}$ jej koncepcją człowieka oraz rozumienia wychowania i jego celów, a także pedagogika otwarta w inspiracji chrześcijańskiej ${ }^{23}$, akcentująca całościowe i wieloaspektowe ujmowanie faktów, zjawisk i okoliczności procesu wychowania i nauczania ${ }^{24}$.

18 Jan Paweł II, „«Zaczyn chrześcijański w działalności wychowawczej». Do delegatów Federacji Instytutów Działalności Wychowawczej, 28 grudnia 1978”, w: Szkoła katolicka w nauczaniu Kościoła. Wybór dokumentów, red. Andrzej Dymer (Szczecin-Warszawa: Centrum Edukacyjne Archidiecezji Szczecińsko-Kamieńskiej, 2002), 87-88.

${ }_{19}$ Kongregacja do Spraw Edukacji Katolickiej, „Szkoła Katolicka” (Rzym, 1977), nr 54-55, w: Szkoła katolicka w nauczaniu Kościoła. Wybór dokumentów, red. Andrzej Dymer (Szczecin-Warszawa: Centrum Edukacyjne Archidiecezji Szczecińsko-Kamieńskiej, 2002), 283.

20 Tamże, nr 47, 281.

${ }^{21}$ Janusz Michalski, „Szkoła katolicka miejscem ewangelizacji”, Forum Teologiczne 4 (2003): $155-175$.

${ }_{22}$ Zob. m.in.: Wychowanie na rozdrożu. Personalistyczna filozofia wychowania, red. Franciszek Adamski (Kraków: Wyd. UJ, 1999); Jerzy Bagrowicz, Stawać się bardziej człowiekiem. Z podstaw edukacji religijnej (Toruń: Wydawnictwo Naukowe UMK, 2008).

${ }^{23}$ Zob. m.in. Marian Nowak, Podstawy pedagogiki otwartej. Ujęcie dynamiczne $w$ inspiracji chrześcijańskiej (Lublin: Redakcja Wydawnictw KUL, 2000).

${ }^{24}$ Kongregacja do Spraw Edukacji Katolickiej, „Świecki katolik świadkiem wiary w szkole” (Rzym, 1982), nr 5, w: Szkoła katolicka, 300. 
Kolejna wspomniana cecha szkoły katolickiej to odwołanie się do czynników nadprzyrodzonych. Wynika ona z faktu, że w swoich działaniach dydaktycznych i wychowawczych placówka odwołuje się do działania łaski Bożej oraz sakramentów, zobowiązując nauczycieli i uczniów do korzystania ze środków nadprzyrodzonych w procesie kształtowaniu charakteru chodzi głównie o sakramenty Eucharystii i pokuty. Jednocześnie wprowadza w praktykę edukacyjną - w celu pobudzania wiary i ufnego oddawania się prowadzeniu Bożemu - rekolekcje, różnego rodzaju nabożeństwa, modlitwy czy pielgrzymki. Przez cechę odwołania się do nadprzyrodzoności szkoła katolicka podkreśla, iż „nie możemy wychować człowieka, jeśli nie wychowamy dziecka Bożego”, ponieważ ,abyśmy mogli iść z ziemi ku niebu, musimy iść z Chrystusem z nieba ku ziemi i z Chrystusem z ziemi i przez ziemię ku niebu" 25 .

Z kolei przez - charakterystyczny także dla szkoły katolickiej - uniwersalizm uwypukla się objęcie wychowaniem i kształceniem każdego człowieka oraz całego człowieka. Prawdę tę zaznaczał papież Pius XI w encyklice o chrześcijańskim wychowaniu młodzieży Divini Illius Magistri, podkreślając, iż zakres wychowawczy posłannictwa Kościoła rozciąga się na wszystkich, bez żadnego ograniczenia ${ }^{26}$, ponieważ każdy człowiek został odkupiony przez Chrystusa. Wskazywał on również, iż „Chrześcijańskie wychowanie obejmuje cały zakres ludzkiego życia fizycznego i duchowego, intelektualnego i moralnego, indywidualnego, rodzinnego i społecznego, (...) żeby je podnieść, nim pokierować i udoskonalić, wedle przykładu i nauki Chrystusa"27. Stąd też szkoła katolicka uwzględnia także w swoich działaniach wychowanie osoby ludzkiej w całej jej pełni, wyrażającej się w otwartości na Boga i podejmującej odpowiedzialność za siebie i za własne życie ${ }^{28}$. Pociąga to za sobą konieczność integralnego rozwoju człowieka, uwzględniającego w procesie socjalizacji także sferę duchową i transcendentną ${ }^{29}$.

Wśród przywołanych powyżej cech szkoły katolickiej w sposób szczególny wyłania się jej praca nad sferą relacji transcendentnych. Aniela Różań-

${ }^{25}$ Wincenty Granat, „Zasady pedagogii katolickiej w świetle dogmatu odkupienia grzechu pierworodnego", Miesięcznik Katechetyczny i Wychowawczy 1-2 (1939): 32.

${ }^{26}$ Pius XI, Encyklika Divini Illius Magistri o chrześcijańskim wychowaniu młodzieży (Rzym, 1929), nr 25.

27 Tamże, nr 95.

${ }^{28}$ Kongregacja do Spraw Edukacji Katolickiej, „Szkoła Katolicka”, nr 31, 278.

${ }^{29}$ Tamże, nr 9, 362. 
ska zauważa, iż człowiek każdej kultury potrzebuje i poszukuje sensu życia w wymiarze transcendentnym, ma określony stosunek do sacrum, które jest dla niego Bogiem, Absolutem. Ta sfera - niezależnie od niejednolitości jej pojmowania - wyznacza dla człowieka każdej kultury wspólny mianownik, który może stanowić podstawę dialogu prowadzącego do wzajemnego zrozumienia, akceptacji, będących celem edukacji międzykulturowej. Warto zatem, aby szkoła - wprowadzając w proces dydaktyczno-wychowawczy edukację dla wielokulturowości - uwzględniała także wymiar religijny ${ }^{30}$.

Dialogu międzykulturowego nie można zatem oderwać od dialogu

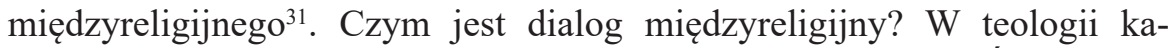
tolickiej podkreśla się, że jego źródłem i wzorem jest Trójca Święta jako jedność i wspólnota Boskich osób oraz sposób postępowania Chrystusa (np. odwołanie się do spotkania Jezusa z Samarytanką J 4, 1-42), a także Boża wola zbawienia wszystkich ludzi (1 Tm 2,4-6). Kluczowej roli w dialogu międzyreligijnym nie odgrywa nawracanie innych, ale wzajemne poznanie się, przełamywanie stereotypów i zrozumienie przedstawicieli innych religii, a także podjęcie współpracy na płaszczyźnie wprowadzania w życie wartości humanistycznych, na przykład wolności religijnej. Chodzi w nim o otwarcie na prawdę i dobro wobec innego człowieka. Jednocześnie dialog międzyreligijny nie oznacza rezygnacji z własnej tożsamości ani ustępstw $\mathrm{w}$ wierze ${ }^{32}$.

Istotą dialogu międzykulturowego jest zatem nie tyle współistnienie odmienności kulturowo-religijnej, co spotkanie między odmiennymi kulturami i religiami. Tak pojęty dialog powinien prowadzić do rozpoznania i uznania różnic oraz wzajemnego szacunku wobec tych różnic ${ }^{33}$. Uwrażliwienie zaś na wartości nierozerwalnie związane z religią katolicką i innymi religiami, jak: sacrum, prawda, dobro, piękno, stanowi podstawę wychowania do człowieczeństwa, a zatem także fundament edukacji dla wielokulturowości.

W tak pojętym dialogu międzykulturowym - na którym zasadzają się niewątpliwie szkoły katolickie - chodzi o wychowanie mające na celu ukształtowanie między ludźmi różnymi kulturowo-religijnie „,komunii”, któ-

30 Orłowska, „Edukacja religijna”, 134.

31 Jarosław Lisica, „Komunikacja międzykulturowa w przestrzeni teologicznej”, Studia Gdańskie 37 (2014): 147-158.

32 Leonard Fic, „Dialog międzyreligijny”, Paedagogia Christiana 2 (2010): 51-64.

33 Orłowska, ,Edukacja religijna”, 141. 
ra - jak nazywał ją Jan Paweł II - ma prowadzić do communio personarum ${ }^{34}$. Ta osobowa komunia ma być przeniknięta kulturą życia, ładu moralnego, sensu życia, także w wymiarze społecznym, obywatelskim, państwowym.

Szkoła katolicka jest jedną z placówek, w której wymiar religijny stanowi o jej istocie. W tym konkretnym przykładzie jest to chrystocentryzm. $\mathrm{W}$ jaki zatem sposób może ona - w swoich cechach determinujących jej tożsamość - otwierać dzieci i młodzież na przyjmowanie inności kulturowo-religijnej?

Jak już wcześniej wspomniałam, dialog międzyreligijny traktowany jest niejednokrotnie jako „specyficzna postać czy forma komunikacji interkulturowej”, której celem ,jest wzajemne poznanie się, wyzwalanie z wirtualnej przestrzeni stereotypów i resentymentów, spojrzenie sobie «twarzą w twarz», zastanawianie się nad prawdą i drogą do niej" ${ }^{35}$. Chrześcijanin, w tym katolik, podejmuje taki dialog z wyznawcami innych kultur i religii ze względu na Chrystusa - najlepszego Nauczyciela porozumienia, a szkoła katolicka opierająca się na chrystocentryzmie ma szansę wychowywać młodych ludzi do prawdziwego dialogu poprzez kształtowanie w nich - jako wyznawcach Jezusa - wiary wyzutej z obojętności i nienawiści, wiary przepełnionej otwartością, twórczością, przekraczaniem siebie. Takie wychowanie oparte jest na ewangelizacyjnej misji Kościoła - dialogu wpisanym w troskę o zbawienie całego człowieka poprzez syntezę kultury i wiary oraz wiary i życia ${ }^{36}$.

$\mathrm{W}$ profilowaniu owego dialogu istotne jest kształtowanie w młodych wrażliwości religijnej, co odbywa się na drodze wychowania do modlitwy dialogu z Bogiem, Absolutem, rozmowy z Nim. Eugeniusz Sakowicz zauważa, iż ,tylko ten, kto się modli, uszanuje drugiego człowieka, «inaczej» się modlącego. Dialog modlitwy to «bycie razem, aby się modlić»». Aby ten stan osiągnąć, trzeba podejmować trud modlenia się, adorowania Boga, kontemplowania Go" ${ }^{37}$. W przypadku szkoły katolickiej jest to zachęta i praktykowanie dialogu z Bogiem jako Trójcą Osób - Bogiem Ojcem, Jezusem Chrystusem i Duchem Świętym.

Kształtowanie owej kontemplacyjnej postawy, czyli dialogu z Bogiem, stanowi fundament „narodzin” w młodych prawdziwej miłości - miłości

${ }^{34}$ Eugeniusz Sakowicz, ,Wychowanie do komunikacji interkulturowej dialogu międzyreligijnego", w: Religia a współczesne stosunki międzynarodowe, red. Bogusława Bednarczyk, Zbigniew Pasek, Piotr Stawiński (Kraków: Oficyna Wydawnicza AFM, 2011), 98.

35 Tamże, 99.

${ }^{36}$ Kongregacja do Spraw Edukacji Katolickiej, ,,Szkoła Katolicka”, nr 38-48, 279-282.

37 Sakowicz, „Wychowanie”, 101. 
osobowej, podmiotowej - w relacji z Bogiem i człowiekiem, każdym człowiekiem, również tym innym. Owa miłość nie ogranicza się do emocji, ale przede wszystkim odwołuje się do bezinteresownego ofiarowania siebie i swoich działań na służbę innego człowieka, niezależnie od jego oblicza kulturowo-religijnego, ponieważ każdy człowiek jest „odbiciem” oblicza Boga $^{38}$. Zatem wychowanie do modlitwy - obecne nieodzowne w szkole katolickiej - uzdalnia człowieka do przyjmowania takiej postawy.

Kolejnym fundamentalnym założeniem szkoły katolickiej, determinującym jej tożsamość, a jednocześnie wpisującym się w edukację dla wielokulturowości, jest pedagogia miłości. Wynika to z faktu, iż miłość Boga ku człowiekowi oraz miłość człowieka ku Bogu i bliźniemu to podstawowe, ewangeliczne przykazania religii katolickiej. W Konstytucji duszpasterskiej o Kościele w świecie współczesnym Gaudium et spes czytamy, że:

Pismo święte (...) poucza (...), że miłości Boga nie można odłączyć od miłości bliźniego, bo: «jeśli jest inne jakie przykazanie, w tym słowie się zamyka: będziesz miłował bliźniego swego jak siebie samego... przeto doskonałym wypełnieniem prawa jest miłość» (Rz 13, 9-10; por. 1 J 4, 20). Że jest to rzeczą bardzo wielkiej wagi, dowodzi fakt, że ludzie z każdym dniem są coraz bardziej od siebie zależni, a świat w coraz wyższym stopniu jest zjednoczony ${ }^{39}$.

Należy tu zaznaczyć, że zarówno Biblia, jak i nauczanie Kościoła nie ograniczają owej miłości bliźniego do katolików, ale rozciągają ją na cały rodzaj ludzki, niezależnie od nacji kulturowo-religijnej.

Następną - wspomnianą powyżej - cechą, tożsamą z pedagogiką katolicką i szkołą katolicką, jest odwołanie do nadprzyrodzoności. W jaki sposób może ona otwierać młodych na człowieka innej kultury i wyznania? Zdaniem Anieli Różańskiej, kultura religijna w wymiarze edukacji dla wielokulturowości powinna umożliwiać

wszystkim uczniom, nawet tym z rodzin bezwyznaniowych, nabywanie wiedzy o «fakcie religijnym», który jest podstawowym wymiarem doświadczenia

38 Dariusz Kurzydło, „Wychowanie do postawy kontemplacyjnej”, w: Chrześcijaństwo wśród religii świata, red. Leonard Fic, Paweł Mazanka, Eugeniusz Sakowicz, Paweł Szuppe, Wanda Zagórska (Warszawa: Wydawnictwo Uniwersytetu Kardynała Stefana Wyszyńskiego, 2017), 305-306.

39 Sobór Watykański II, Konstytucja duszpasterska o Kościele w świecie współczesnym Gaudium et spes (Rzym, 1965), nr 24. 
ludzkiego. Nabywanie takiej wiedzy powinno się rozpoczynać od poznania dziedzictwa doświadczenia religijnego i języka symboli świata uczniów i tradycji, w których uczestniczą, przez poznawanie innych religii w innych manifestacjach kulturowych, wreszcie poprzez porównywanie różnych rzeczywistości religijnych oraz fenomenologiczne poszukiwanie wspólnych wartości i sensu ${ }^{40}$.

Zastrzeżenia może budzić tu fakt, że szkoła katolicka jest placówką o określonym światopoglądzie religijnym. Beata Orłowska zaznacza jednak, iż jednym z ważnych elementów przygotowania młodych na spotkanie $\mathrm{z}$ innością jest dobre poznanie własnej religii ${ }^{41}$. Głębokie zakorzenienie w swojej konfesji bez ideologii fanatyzmu może otwierać na człowieka reprezentującego inną kulturę i religię. Jak wskazuje Kongregacja do Spraw Edukacji Katolickiej, szkoła katolicka jest w tym zakresie daleka od kształtowania w wychowankach postawy zamkniętej i konfliktowej. Buduje w nich nastawienie przepełnione otwartością na spotkanie „ku innym w duchu tolerancji i szacunku dla ich sposobu myślenia i życia, w zrozumieniu ich trosk i nadziei, dzieląc ich dole i uczestnicząc w ich stawaniu się"42.

Kolejną cechą stanowiącą o tym, że dana szkoła i pedagogika są katolickie, jest uniwersalizm. On również może być ważnym elementem budowania właściwych relacji międzyludzkich w odmiennych kulturach i światopoglądach zaangażowanych w relację osób. Poprzez tę cechę szkoła katolicka obejmuje wychowaniem każdego człowieka. Niniejsza deklaracja widoczna jest już w procesie rekrutacji, w której placówka ta jest zobowiązana do przyjęcia ucznia niebędącego katolikiem oraz poszanowania i respektowania jego odmienności kulturowo-religijnej. Deklarację taką odnajdujemy w statutach polskich szkół katolickich zrzeszonych w Radzie Szkół Katolickich. Mówią one, iż:

szkoła jest otwarta na przyjmowanie uczniów z rodzin wyznających inną religię, poszukujących i niewyznających żadnej religii, których rodzice wybierają tę szkołę jako miejsce edukacji swoich dzieci. Szanując ich przekonania, szkoła zapewnia wszystkim uczniom wychowanie do wzajemnego szacunku, pokoju i współpracy - w klimacie chrześcijańskiej otwartości i miłości ${ }^{43}$.

${ }^{40}$ Cyt. za: Orłowska, „Edukacja religijna”, 135.

${ }^{41}$ Tamże, 138.

${ }^{42}$ Kongregacja do Spraw Edukacji Katolickiej, „Szkoła Katolicka”, nr 57, 283-284.

${ }^{43}$ Rada Szkół Katolickich, Wzór zapisów statutu. Statut Publicznej Katolickiej Szkoły Podstawowej [wersja elektroniczna] (Warszawa, 2014), art. 9. 
Zapewniają także, że „uczniowie niewierzący lub wyznający inną religię korzystają z przysługującej im wolności sumienia i wyznania w zakresie praktyk religijnych" 44 .

Kongregacja do Spraw Edukacji Katolickiej przyznaje, iż do szkół katolickich uczęszczają także uczniowie niewyznający wiary katolickiej lub niewierzący, a z uwagi na to, iż wiara nie dopuszcza przemocy, wychowawcy mają obowiązek z szacunkiem odnosić się do wolności tych uczniów oraz $\mathrm{z}$ otwartością i życzliwością podejmować $\mathrm{z}$ nimi dialog ${ }^{45}$. Wynika to $\mathrm{z}$ faktu wolności „z mocą bronionej przez Kościół”, co w konsekwencji oznacza dla katolickich placówek głoszenie orędzia zbawienia i wartości chrześcijańskich bez ich narzucania, bez użycia moralnej przemocy ${ }^{46}$.

\section{Rola wychowania obywatelskiego w szkole katolickiej w budowaniu społeczeństwa wielokulturowego}

Ważnym elementem edukacji osobowo-obywatelskiej jest przygotowanie dzieci i młodzieży do przyjęcia $\mathrm{z}$ otwartością ludzi o odmiennych kulturach i religiach ${ }^{47}$. W jakim zakresie szkoła katolicka, respektując podmiotowość każdego człowieka - niezależnie od kultury i konfesji, które go ukształtowały - realizuje wychowanie obywatelskie wobec swoich uczniów, kierując się nauczaniem Kościoła katolickiego i reprezentując konkretny światopogląd w ramach realizowanego procesu dydaktyczno-wychowawczego ${ }^{48}$

Z samego swego założenia szkoła katolicka - w całym swym działaniu, również w zakresie wychowania obywatelskiego - jest otwarta na wszystkich bez względu na wyznanie czy światopogląd, ponieważ jej celem - tak jak innych szkół - jest ,prawdziwie ludzka formacja” młodych. Stąd też jest

44 Tamże, art. 10.

${ }^{45}$ Kongregacja do Spraw Edukacji Katolickiej, „Świecki katolik”, nr 6, 309-310.

${ }^{46}$ Kongregacja do Spraw Edukacji Katolickiej, ,Religijny wymiar wychowania w szkole katolickiej” (Rzym, 1988), nr 6, w: Szkota katolicka, 324-325.

47 Orłowska, „Edukacja religijna”, 139.

48 Niniejszą problematykę podjęłam także w artykule: Aldona Zakrzewska, „Różnorodność kulturowo-wyznaniowa społeczeństwa wyzwaniem dla wychowania obywatelskiego w szkole katolickiej”, w: Religia i edukacja w styczności z różnorodnościa kulturową, red. Joanna M. Garbula, Jacek J. Pawlik (Olsztyn: Wydawnictwo Uniwersytetu Warmińsko-Mazurskiego w Olsztynie, 2017), 89-103. 
ona placówką, w której obecna jest edukacja „w duchu ekumenizmu oraz w szacunku dla każdego człowieka", każdego obywatela ${ }^{49}$.

Niezwykle istotnym rysem wychowania obywatelskiego jest ukształtowanie $\mathrm{w}$ dzieciach i młodzieży potrzeby służenia dla dobra wszystkich obywateli państwa. Stąd też wydaje się, iż nieodzownym i pierwszoplanowym celem wychowania interkulturowego i międzyreligijnego powinno być ukierunkowanie wychowanka na wartość innej kultury i religii - a zatem w polskiej szkole katolickiej na wyznania niebędące konfesją katolicką i inne religie oraz kultury niewchodzące w orbitę kultury chrześcijańskiej. Szkoła katolicka stara się zatem - wychodząc naprzeciw tym potrzebom - przybliżać uczniom inne kultury i religie, głównie przez poszerzanie ich wiedzy w ramach przedmiotowego nauczania, a także przez organizowanie spotkań z misjonarzami, którzy stanowią niezwykłą kopalnię informacji o ludziach innych kultur i religii, wśród których przebywają na co dzieńn ${ }^{50}$.

Eugeniusz Sakowicz czy przywoływany już Jerzy Nikitorowicz zauważają jednak, że tak jednostronne ukierunkowanie nie doprowadzi do humanizacji stosunków międzykulturowych i międzyreligijnych. Może być nawet ślepym zaułkiem. Podkreślają oni, iż na pierwszym planie edukacji interkulturowej i międzyreligijnej powinno być poznanie wartości własnej kultury i religii, a dopiero później innych ${ }^{51}$. Wynika to z faktu, iż - jak podkreśla E. Sakowicz:

wychowanie do komunikacji interkulturowej jest wychowaniem do afirmacji własnej tożsamości. Ma na celu przylgnięcie do tradycji, zakorzenienie w przeszłości, bez której nie ma przyszłości. Komunikacja międzykulturowa może mieć miejsce wtedy, gdy dwie (lub więcej) strony traktowane są jako równorzędni partnerzy. Pycha kulturowa oznacza zafałszowanie własnego wizerunku. «Ktoś» (np. naród, dana kultura, społeczność) o «twarzy» zafałszowanej, o «obliczu» niewyraźnym, koniunkturalnym nigdy nie będzie zdolny stanąć przed prawdą o sobie. Nie potrafi zaangażować się w porozumiewanie się, in-

49 II Polski Synod Plenarny (1991-1999), „Nauczanie Kościoła o szkole i uniwersytecie” (Poznań, 2001), nr 12, w: Szkoła katolicka, 373.

${ }^{50}$ Doświadczenia własne jako członka Stowarzyszenia Świętej Rodziny w Olsztynie (od 1997 r.), które jest organem założycielskim i prowadzącym cztery placówki katolickie w Olsztynie (przedszkole, szkołę podstawową, gimnazjum, liceum).

51 Jerzy Nikitorowicz, ,Idee edukacji międzykulturowej w dobie globalizacji i regionalizacji”, w: Edukacja jutra: XI Tatrzańskie Seminarium Naukowe, red. Franciszek Bereźnicki, Kazimierz Denek (Szczecin: Uniwersytet Szczeciński, 2005), 51-58; Sakowicz, „Wychowanie”, 97. 
terakcje, komunikację, obustronny «ruch» myśli, pragnień, słów, w obopólne milczenie ${ }^{52}$.

W polskiej szkole katolickiej poznaniu i zakorzenieniu w religii rzymskokatolickiej służy chrystocentryzm, obecny w każdym wymiarze procesu dydaktyczno-wychowawczego placówki, który przybliżyłam pokrótce w drugiej części artykułu. Dodatkowo istotną rolę - głównie w aspekcie zakorzenienia we własnej kulturze - spełnia szeroko pojęte wychowanie patriotyczne, obejmujące swoim zakresem także omawiane wychowanie obywatelskie. W ramach wychowania patriotycznego istotne posłannictwo spełnia - starannie rozwijana w polskiej szkole katolickiej - edukacja narodowa i regionalna, ujmowana w jej dawnych programach wychowawczych, a obecnie w programach profilaktyczno-wychowawczych ${ }^{53}$. Ukształtowanie poczucia własnej tożsamości małej i wielkiej ojczyzny stanowi fundament powodzenia edukacji wielokulturowej, co podkreśla wielu autorów pozycji z zakresu tej problematyki, m.in. Jerzy Nikitorowicz ${ }^{54}$, Mariusz Samoraj ${ }^{55}$, Renata Mistarz $^{56}$ czy Beata Orłowska ${ }^{57}$.

Badania nad polskim szkolnictwem katolickim (2001 r. - Adam Maj) wskazują, iż istotne w hierarchii jej celów jest wychowanie w duchu tradycji, historii i kultury narodowej, umiłowania Boga i Ojczyzny, przy jednoczesnym szacunku wobec innych kultur i religii $(83,6 \%$ badanych dyrektorów szkół podstawowych; 54,5\% szkół zawodowych; 72,2\% liceów) ${ }^{58}$.

Wychowanie obywatelskie obecne w szkole katolickiej uwzględnia także wychowanie do uczestnictwa w dialogach międzykulturowym i międzyreligijnym - o których wspominałam w drugiej części rozważań - wy-

52 Sakowicz, „Wychowanie”, 98.

${ }^{53}$ Doświadczenia własne.

${ }^{54}$ Jerzy Nikitorowicz, „Edukacja regionalna jako podstawa kreowania społeczeństwa obywatelskiego", w: Kierunki rozwoju edukacji w zmieniajacej sie przestrzeni społecznej. Ksiegga Jubileuszowa dedykowana profesorowi doktorowi habilitowanemu Michałowi Balickiemu, red. Agata Cudowska (Białystok: Trans Humana, 2011), 23-32.

55 Mariusz Samoraj, „Edukacja wielokulturowa na rozdrożu”, Przyszłość: Świat - Europa - Polska 1 (2014): 119-121.

${ }^{56}$ Renata Mistarz, „Wielokulturowość a edukacja regionalna”, Informator Oświatowy 3 (2011): 29-31.

${ }^{57}$ Beata A. Orłowska, „Edukacja regionalna w wielokulturowej społeczności”, Edukacja Elementarna w Teorii i Praktyce 1-2 (2010): 34-42.

58 Adam Maj, Szkolnictwo katolickie w III RP (1989-2001) (Warszawa: Wyd. „Adam”, 2002), 239, 240. 
pływającego z ewangelizacyjnej misji Kościoła. Charakteryzuje się ono „ukształtowaniem dobrego, uczciwego człowieka, kierującego się pokorą, czyli prawdą o sobie, stroniącego od pychy, odrzucającego zafałszowany obraz siebie" 59 . Przywołane badania Adama Maja pokazują, iż niektórzy dyrektorzy polskich szkół katolickich swoje działania ukierunkowują na pełny rozwój ucznia, obejmując także sferę duchową i transcendentną wychowanków (między 62 a 70\% dyrektorów szkół podstawowych) ${ }^{60}$.

W wychowaniu obywatelskim istotne jest także ukształtowanie w młodych otwartości na dialog społecznego zaangażowania, społecznego działania. W swoim założeniu na płaszczyźnie nauki Kościoła rzymskokatolickiego, stanowiącej podstawę wychowania obywatelskiego szkoły katolickiej, jest on „opowiedzeniem się za prawem i sprawiedliwością w życiu społecznym; (...) odważnym przeciwstawianiem się nędzy, ubóstwu, wyzyskowi kulturowemu, materialnemu, prostytucji, pornografii, apoteozie perwersji moralnych w życiu publicznym. Przygotowanie do tego dialogu polega na kształtowaniu w sobie wrażliwości moralnej" ${ }^{61}$. Badania - o których wspominałam powyżej, przeprowadzone przez Adama Maja - wskazują, iż wychowanie do wartości społecznych i moralnych odgrywa w polskich szkołach katolickich istotną rolę. W gimnazjach katolickich $62,3 \%$, a w liceach 64,4\% badanych dyrektorów eksponuje w swoich działaniach „kształtowanie i wychowanie uczniów w duchu odpowiedzialności za siebie i innych, w życiu osobistym, społecznym i rodzinnym"62. Niniejsze dane wskazują na respektowanie zaleceń Kongregacji do Spraw Edukacji Katolickiej, która podkreśla, iż szkoła katolicka musi być powiązana z polityką, ekonomią i kulturą, a także ze społeczeństwem jako całością ${ }^{63}$. Powinna zatem wychowywać w służbie na rzecz wspólnego dobra społeczeństwa, ludzkości, kształtując w dzieciach i młodzieży postawy obywatelskie, takie jak: wolność, sprawiedliwość, praca, postęp ${ }^{64}$.

Niezwykłą pomocą w formowaniu obywatelskich postaw dzieci i młodzieży w szkole katolickiej, ukierunkowanych na działanie na rzecz dobra wszystkich obywateli niezależnie od ich tożsamości kulturowo-reli-

\footnotetext{
59 Sakowicz, „Wychowanie”, 101.

${ }^{60}$ Maj, Szkolnictwo, 239, 240, 241.

${ }^{61}$ Sakowicz, „Wychowanie”, 101-102.

${ }^{62}$ Maj, Szkolnictwo, 240.

${ }^{63}$ Kongregacja do Spraw Wychowania Katolickiego, „Szkoła Katolicka u progu”, nr 16 ,
} 365.

${ }^{64}$ Kongregacja do Spraw Edukacji Katolickiej, „Religijny wymiar”, nr 45-46, 335. 
gijnych, są wszelkiego rodzaju praktyki kształtujące w młodych postawę kontemplacyjną - wspomnianą $\mathrm{w}$ drugiej części artykułu - określaną mianem postawy podmiotowej, osobowej z Bogiem, a w konsekwencji z każdym człowiekiem jako stworzeniem Bożym, będącym Jego „odbiciem”. Są to między innymi: Eucharystia, adoracja, modlitwa, nabożeństwa, katecheza, rekolekcje, pielgrzymki, spotkania z misjonarzami, kapłanami i osobami konsekrowanymi ${ }^{65}$. To one pokazują młodym, iż - jak głosi Konstytucja duszpasterska o Kościele w świecie współczesnym Gaudium et spes:

Bóg troszczący się po ojcowsku o wszystko chciał, by wszyscy ludzie tworzyli jedną rodzinę i odnosili się wzajemnie do siebie w duchu braterskim. Wszyscy bowiem, stworzeni na obraz Boga, który «z jednego uczynił cały rodzaj ludzki, aby zamieszkał cały obszar ziemi» (Dz 17, 26), powołani są do jednego i tego samego celu, to jest do Boga samego. (...) Kiedy Pan Jezus modli się do Ojca, aby «wszyscy byli jedno... jako i my jedno jesteśmy» (J 17, 21-22), otwierając przed rozumem ludzkim niedostępne perspektywy, daje znać o pewnym podobieństwie między jednością osób boskich a jednością synów Bożych zespolonych w prawdzie i miłości. To podobieństwo ukazuje, że człowiek będąc jedynym na ziemi stworzeniem, którego Bóg chciał dla niego samego, nie może odnaleźć się w pełni inaczej jak tylko poprzez bezinteresowny dar z siebie samego ${ }^{66}$.

Zatem wartości transcendentne - wszechobecne w procesie dydaktyczno-wychowawczym polskiej szkoły katolickiej (95\% badanych przez Adama Maja dyrektorów katolickich szkół podstawowych, 80,3\% gimnazjów i $96,7 \%$ liceów podkreślało, iż ,wiodącym zadaniem jest organizowanie działalności wychowawczo-dydaktycznej w oparciu o chrześcijański system wartości, Ewangelię i Naukę Kościoła" ${ }^{67}$ ) - otwierają jej uczniów na osobową relację z Bogiem oraz podmiotową relację z drugim człowiekiem w kategoriach szeroko pojętej edukacji dla wielokulturowości.

Wszystko to wynika z faktu, iż szkoła katolicka - zgodnie ze wskazaniem Kongregacji do Spraw Edukacji Katolickiej - ukazane cele, formy i środki wychowania obywatelskiego oferuje każdemu uczniowi, który

\footnotetext{
${ }^{65}$ Doświadczenia własne.

${ }^{66}$ Sobór Watykański II, Konstytucja, nr 24.

${ }^{67}$ Maj, Szkolnictwo, 238, 239.
} 
w niej się kształci, w tym także „niechrześcijanom, uznając i szanując dobra duchowe oraz wartości społeczno-kulturalne różnych cywilizacji”68.

\section{Zakończenie}

Wielorakość kulturowo-religijna jest czymś oczywistym, a jej źródło na przestrzeni dziejów w poszczególnych regionach i społeczeństwach ma złożony charakter. Niezaprzeczalny jest jednak fakt, iż poszczególne kultury i cywilizacje tworzone są przez określone jednostki. Stąd też spotkanie danych kultur, religii czy narodowości to w pierwotnej płaszczyźnie spotkanie poszczególnych osób - spotkanie człowieka z człowiekiem ${ }^{69}$. Zatem podstawę edukacji międzykulturowej stanowi wychowanie do bycia człowiekiem w relacji z człowiekiem, do stawania się człowiekiem. To zaś odnajdujemy w wychowaniu obywatelskim szkół katolickich, opartym na miłości Boga i bliźniego, a także wychowaniu wszechstronnym, obejmującym każdego człowieka z jego różnorodnością etniczną, narodową czy wyznaniową i każdą jego sferę. Należy jednak pamiętać, iż - tak jak inne płaszczyzny wychowania - również ta może przynieść pozytywne skutki pod warunkiem podjęcia konstruktywnej i właściwie ukierunkowanej współpracy ze szkołą przez inne środowiska wychowawcze, w tym przede wszystkim przez rodzinę.

Szkoła katolicka przeniknięta jest konfesyjną edukacją religijną, co nie musi stanowić przeszkody w edukacji dla wielokulturowości, ale może być jej atutem. Wynika to z faktu, iż istnieją pewne wspólne elementy łączące wychowanie religijne $\mathrm{z}$ edukacją dla wielokulturowości. W ich zakres wchodzą między innymi formowanie humanistycznych postaw, nawyków i wartości moralnych oraz kształtowanie poszanowania odmiennych wartości i sposobów życia oraz akceptacji inności czy zasad tolerancji. Chodzi o to, aby młodych przygotować do tworzenia cywilizacji miłości, do czego w całej pełni wzywa Ewangelia i nauczanie Kościoła rzymskokatolickiego.

Szkoła katolicka ma w edukacji dla wielokulturowości do odegrania specjalną misję - pobudzania społeczeństwa do budowania w społeczności wielorakiej religijnie i kulturowo dialogu oraz współpracy przez swój oży-

${ }^{68}$ Kongregacja do Spraw Edukacji Katolickiej, ,Szkoła Katolicka”, nr 85, 291.

${ }^{69}$ Mirosław Pawliszyn, „O Spotkaniu kultur - dopowiedzenie filozoficzne”, w: Religia i edukacja w styczności z różnorodnościa kulturową, red. Joanna M. Garbula, Jacek J. Pawlik (Olsztyn: Wydawnictwo Uniwersytetu Warmińsko-Mazurskiego w Olsztynie, 2017), 18, 27-29. 
wiony i aktywny chrystianizm ${ }^{70}$. Kościół wskazuje, iż taka placówka edukacyjna „wnosi do dialogu kulturowego oryginalny wkład na rzecz prawdziwego postępu i integralnego kształtowania człowieka"71.

\section{The Cultural-Religious Diversity and Civic Upbringing at the Catholic School (Summary)}

The basis for the discussion is civic upbringing which is introduced in Catholic schools in the spirit of openness of the children and teenagers to the cultural-religious diversity which is more and more visible in the Polish social reality. It is especially difficult from the social perspective. On the one hand each group wants to live in tolerance, on the other hand it wants to keep its identity. Besides it is not easy in the perspective of the mission of the Catholic school. It results from the fact that although it declares building unity in diversity, the educational and upbringing process of the school determines the specific point of view.

Keywords: civic education; Catholic schools; education for multiculturalism.

\section{Wielorakość kulturowo-religijna a wychowanie obywatelskie w szkole katolickiej (Streszczenie)}

Podstawę rozważań stanowi wychowanie obywatelskie podejmowane w szkołach katolickich w duchu otwartości dzieci i młodzieży na różnorodność kulturowo-religijną, która w polskiej rzeczywistości społecznej jest coraz bardziej widoczna. Jest to niezwykle trudne $z$ punktu widzenia społecznego. $Z$ jednej bowiem strony każda $\mathrm{z}$ grup pragnie żyć w poczuciu tolerancji, $\mathrm{z}$ drugiej natomiast chce zachować swą tożsamość. Poza tym nie jest to łatwe w perspektywie misji szkoły katolickiej. Wynika to z faktu, że wprawdzie deklaruje ona budowanie jedności w różnorodności, jednak jej proces dydaktyczno-wychowawczy determinuje konkretny światopogląd.

Stowa kluczowe: wychowanie obywatelskie; szkoły katolickie; edukacja dla wielokulturowości.

${ }^{70}$ Kongregacja do Spraw Edukacji Katolickiej, ,Szkoła Katolicka”, nr 12, 274.

71 Tamże, nr 15, 274. 


\section{Bibliografia}

Bagrowicz, Jerzy. Stawać się bardziej czlowiekiem. Z podstaw edukacji religijnej. Toruń: Wydawnictwo Naukowe UMK, 2008.

Bartz, Brunon. Idea wielokulturowego wychowania $w$ nowoczesnych spoleczeństwach. Radom: Instytut Technologii Eksploatacji, 1997.

Borden, George A. „Orientacja kulturowa. Teoria służąca rozumieniu i badaniom komunikacji międzykulturowej”. W: Komunikacja międzykulturowa: zderzenia i spotkania, red. Alina Kapciak, Leszek Korporowicz, Andrzej Tyszka, 57-76. Warszawa: Instytut Kultury Uniwersytetu Warszawskiego, 1996.

Collier, Michael J. „Rozmowy między rodzimymi grupami kulturowymi: różnice kompetencji międzykulturowych". W: Komunikacja międzykulturowa: zderzenia i spotkania, red. Alina Kapciak, Leszek Korporowicz, Andrzej Tyszka, 323-337. Warszawa: Instytut Kultury Uniwersytetu Warszawskiego, 1996.

Edukacja obywatelska w społeczeństwach wielokulturowych, red. Alicja Szerląg. Kraków: Oficyna Wydawnicza „Impuls”, 2007.

Fic, Leonard. „Dialog międzyreligijny”. Paedagogia Christiana 2 (2010): 51-64.

Golka, Marian. „Doświadczanie tożsamości w warunkach wielokulturowości”. Przeglad Zachodni 1 (2012): 3-16.

Golka, Marian. „Kształty wielokulturowości”. Pampaedia 6/7 (2009/2010): 7-21.

Golka, Marian. „Zadania i nadzieje edukacji dla wielokulturowości”. Europa Wschodu i Zachodu 4 (2000): 12-16.

Golka, Marian. Imiona wielokulturowości. Warszawa: Warszawskie Wydawnictwo Literackie MUZA SA, 2010.

Granat, Wincenty. „Zasady pedagogii katolickiej w świetle dogmatu odkupienia grzechu pierworodnego". Miesięcznik Katechetyczny i Wychowawczy 1-2 (1939): $30-49$.

II Polski Synod Plenarny (1991-1999). „Nauczanie Kościoła o szkole i uniwersytecie”. Poznań 2001. W: Szkoła katolicka w nauczaniu Kościoła. Wybór dokumentów, red. Andrzej Dymer, 371-375. Szczecin-Warszawa: Centrum Edukacyjne Archidiecezji Szczecińsko-Kamieńskiej, 2002.

Jan Paweł II, „«Zaczyn chrześcijański w działalności wychowawczej». Do delegatów Federacji Instytutów Działalności Wychowawczej, 28 grudnia 1978”. W: Szkoła katolicka w nauczaniu Kościoła. Wybór dokumentów, red. Andrzej Dymer, 87-88. Szczecin-Warszawa: Centrum Edukacyjne Archidiecezji Szczecińsko-Kamieńskiej, 2002. 
Kongregacja do Spraw Edukacji Katolickiej. „Szkoła Katolicka”. Rzym, 1977. W: Szkoła katolicka w nauczaniu Kościoła, 271-294. Szczecin-Warszawa: Centrum Edukacyjne Archidiecezji Szczecińsko-Kamieńskiej: 2002.

Kongregacja do Spraw Edukacji Katolickiej. „Świecki katolik świadkiem wiary w szkole”. Rzym, 1982. W: Szkoła katolicka w nauczaniu Kościoła, 295-322. Szczecin-Warszawa: Centrum Edukacyjne Archidiecezji Szczecińsko-Kamieńskiej: 2002.

Kongregacja do Spraw Wychowania Katolickiego. „Religijny wymiar wychowania w szkole katolickiej”. Rzym, 1988. W: Szkoła katolicka w nauczaniu Kościoła, 321-358. Szczecin-Warszawa: Centrum Edukacyjne Archidiecezji Szczecińsko-Kamieńskiej: 2002.

Kongregacja do Spraw Wychowania Katolickiego. „Szkoła Katolicka u progu trzeciego tysiąclecia”. Rzym, 1997. W: Szkoła katolicka w nauczaniu Kościoła, 359-367. Szczecin-Warszawa: Centrum Edukacyjne Archidiecezji Szczecińsko-Kamieńskiej: 2002.

Kurzydło, Dariusz. „Wychowanie do postawy kontemplacyjnej”. W: Chrześcijaństwo wśród religii świata, red. Leonard Fic, Paweł Mazanka, Eugeniusz Sakowicz, Paweł Szuppe, Wanda Zagórska, 297-310. Warszawa: Wydawnictwo Uniwersytetu Kardynała Stefana Wyszyńskiego, 2017.

Lisica, Jarosław. „Komunikacja międzykulturowa w przestrzeni teologicznej”. Studia Gdańskie 37 (2014): 147-158.

Maj, Adam. Szkolnictwo katolickie w III RP (1989-2001). Warszawa: Wyd. „Adam”, 2002.

Michalski, Janusz. „Szkoła katolicka miejscem ewangelizacji”. Forum Teologiczne 4 (2003): 155-175.

Miluska, Jolanta. „Ku tolerancji: program wspomagania rozwoju tożsamości kulturowej”. W: Edukacja międzykulturowa. W kręgu potrzeb, oczekiwań i stereotypów, red. Jerzy Nikitorowicz, 302-325. Białystok: Trans Humana, 1995.

Mistarz, Renata. „Wielokulturowość a edukacja regionalna”. Informator Oświatowy 3 (2011): 29-31.

Nikitorowicz, Jerzy. „Edukacja międzykulturowa w procesie przeciwstawiania się dehumanizacji i infrahumanizacji”. Edukacja Międzykulturowa 1 (2017): 19-35.

Nikitorowicz, Jerzy. „Edukacja regionalna jako podstawa kreowania społeczeństwa obywatelskiego". W: Kierunki rozwoju edukacji w zmieniajacej się przestrzeni społecznej. Ksiega Jubileuszowa dedykowana profesorowi doktorowi habilitowanemu Michałowi Balickiemu, red. Agata Cudowska, 23-32. Białystok: Trans Humana, 2011.

Nikitorowicz, Jerzy. „Idee edukacji międzykulturowej w dobie globalizacji i regionalizacji”. W: Edukacja jutra: XI Tatrzańskie Seminarium Naukowe, red. Fran- 
ciszek Bereźnicki, Kazimierz Denek, 51-58. Szczecin: Uniwersytet Szczeciński, 2005.

Nikitorowicz, Jerzy. „Ku jakim strategiom w edukacji międzykulturowej w kontekście współczesnych problemów wielokulturowości?”. Pogranicze 25 (2015): $25-40$.

Nikitorowicz, Jerzy. Edukacja regionalna i międzykulturowa. Warszawa: Wydawnictwa Akademickie i Profesjonalne, 2009.

Nowak, Marian. Podstawy pedagogiki otwartej. Ujęcie dynamiczne $w$ inspiracji chrześcijańskiej. Lublin: Redakcja Wydawnictw KUL, 2000.

Orłowska, Beata A. „Edukacja regionalna w wielokulturowej społeczności”. Edukacja Elementarna w Teorii i Praktyce 1-2 (2010): 34-42.

Orłowska, Beata A. „Edukacja religijna jako podstawa dialogu między kulturami”. Perspectiva. Legnickie Studia Teologiczno-Historyczne 2 (2012): 130-143.

Pawliszyn, Mirosław. „O Spotkaniu kultur - dopowiedzenie filozoficzne”. W: Religia i edukacja w styczności z różnorodnością kulturowa, red. Joanna M. Garbula, Jacek J. Pawlik, 17-29. Olsztyn: Wydawnictwo Uniwersytetu Warmińsko-Mazurskiego, 2017.

Pius XI. Encyklika Divini Illius Magistri o chrześcijańskim wychowaniu młodzieży. Rzym, 1929.

Rada Szkół Katolickich. Wzór zapisów statutu. Statut Publicznej Katolickiej Szkoły Podstawowej [wersja elektroniczna]. Warszawa, 2014.

Sakowicz, Eugeniusz. „Wychowanie do komunikacji interkulturowej dialogu międzyreligijnego". W: Religia a wspótczesne stosunki międzynarodowe, red. Bogusława Bednarczyk, Zbigniew Pasek, Piotr Stawiński, 95-104. Kraków: Oficyna Wydawnicza AFM, 2011.

Samoraj, Mariusz. „Edukacja wielokulturowa na rozdrożu”. Przyszłość: Świat - Europa - Polska 1 (2014): 119-121.

Sobór Watykański II. Konstytucja duszpasterska o Kościele w świecie współczesnym Gaudium et spes. Rzym, 1965.

Szerląg, Alicja. Ku wielokulturowości: aksjologiczny sens wychowania w rodzinie na litewskim pograniczu kulturowym. Kraków: Oficyna Wydawnicza Impuls, 2001.

Wychowanie na rozdrożu. Personalistyczna filozofia wychowania, red. Franciszek Adamski. Kraków: Wyd. UJ, 1999.

Zakrzewska, Aldona. „Różnorodność kulturowo-wyznaniowa społeczeństwa wyzwaniem dla wychowania obywatelskiego w szkole katolickiej”. W: Religia i edukacja w styczności z różnorodnościa kulturową, red. Joanna M. Garbula, Jacek J. Pawlik, 89-103. Olsztyn: Wydawnictwo Uniwersytetu Warmińsko-Mazurskiego, 2017. 